\title{
EFFECTS OF TEMPERATURE AND SALINITY ON SURVIVAL, GROWTH AND FECUNDITY OF THE BRINE SHRIMP ARTEMIA PARTHENOGENETICA FROM SRI LANKA
}

\author{
M.M. KURUPPU' ${ }^{1}$ and S.U.K. EKARATNE ${ }^{2}$ \\ ${ }^{1}$ National Aquatic Resources Agency, Crow Island, Colombo 15. \\ ${ }^{2}$ Department of Zoology, University of Colombo, Colombo 3.
}

\section{(Received: 18 January 1995; accepted: 03 November 1995)}

\begin{abstract}
Survival, growth and reproductive mode were studied in Dunaliella fed Sri Lankan Artemia parthenogenetica raised from hatching to reproductive maturity at different salinity and temperature combinations. Survival was high in 100 and $120 \mathrm{ppt}$, both at $25^{\circ}\left(94\right.$ and $72 \%$, respectively) and $29^{\circ} \mathrm{C}$ ( 82 and $78 \%$, respectively). Poor survival was recorded in higher salinities at $29^{\circ} \mathrm{C}$ and all salinities at $35^{\circ} \mathrm{C}$. At $21^{\circ} \mathrm{C}$ survival decreased rapidly to near $10 \%$, other than in 65 ppt where survival was $48 \%$. Growth rate at the tested salinities varied from $0.11 \mathrm{~mm}$ day $^{-1}$ to $0.16 \mathrm{~mm}^{-1 a y^{-1}}$ at $21^{\circ} \mathrm{C}$ and from $0.23 \mathrm{~mm}$ day ${ }^{-1}$ to $0.34 \mathrm{~mm}$ day $^{-1}$ at $25^{\circ} \mathrm{C}$. Similar growth $\left(0.39 \mathrm{~mm} \mathrm{day}^{-1}\right)$ occurred in 100 and $120 \mathrm{ppt}$ at $29^{\circ} \mathrm{C}$. No animals reached adult stage at $21^{\circ} \mathrm{C}$ whereas at $25^{\circ}$ and $29^{\circ} \mathrm{C}$, broodpouch development commenced by day 14 in 65,80 and 100 ppt. Reproduction occurred only at $29^{\circ} \mathrm{C}$. Ovoviviparity occurred only in the 35 and 100 ppt treatments on day 15 (at 68 and 56 nauplii day ${ }^{-1}$, respectively). Subsequent gradual increase in salinity (4ppt day ${ }^{-1}$ ) in the 35 and 100 ppt treatments made the ovoviviparous groups to switch to oviparity at 132ppt (at 37 cysts adult $^{-1}$ ) and 136 ppt (at 38 cysts adult $^{-1}$ ), respectively. Animals reared in $120 \mathrm{ppt}$ also reproduced, but without switching, showing oviparity (at 36 cysts adult $^{-1}$ ) with gradual salinity increase to $140 \mathrm{ppt}$. Salinity-temperature combinations ranging from 100 to $120 \mathrm{ppt}$ and $25^{\circ}$ to $30^{\circ} \mathrm{C}$ are, therefore, best for survival, growth and reproduction of Sri Lankan Artemia.
\end{abstract}

Key words: Artemia, cysts, Dunaliella, growth, nauplii, reproduction, salinity, survival, temperature.

\section{INTRODUCTION}

The brine shrimp Artemia is widely used as a larval feed in fish and shellfish hatcheries. Natural populations of Artemia inhabit geographically isolated biotopes having specific biotic and abiotic conditions. ${ }^{1}$ In Sri Lanka, a parthenogenetic strain of Artemia inhabits solar salterns in Hambantota and Puttalam. ${ }^{2,3}$ The abiotic conditions of Artemia biotopes show substantial differences in water temperature and salinity. ${ }^{4}$ Such differences and the commercial importance of Artemia have prompted studies into many of its known species and strains with respect to their temperature and/or salinity effects on survival, ${ }^{1}$ growth and mortality ${ }^{5-7}$ and maturation and fecundity. ${ }^{8}$ Results from these studies have illustrated the variation in temperature and salinity responses between Artemia strains. These findings have served to highlight the importance of selecting optimal ranges for known strains of Artemia for specific aquacultural applications. ${ }^{1}$

Salinity and temperature effects on the life cycle of Sri Lankan Artemia parthenogenetica are not documented. The promotion of a wider utilization and export of local Artemia parthenogenetica requires such data that are necessary 
to determine optimum conditions for inoculating Artemia culture ponds. Field culture requires the introduction of the nauplius stage individuals directly into culture ponds. ${ }^{9}$ Their subsequent survival, growth and reproduction under prevailing salinity and temperature conditions determine the size of the final cyst producing population. This paper reports on salinity and temperature effects on life cycle characteristics of the Sri Lankan Artemia parthenogenetica.

\section{METHODS AND MATERIALS}

Artemia parthenogenetica cysts produced in Mahalewaya saltern, Hambantota, were used for studying survival, growth and fecundity at different salinities and temperatures. Artemia cysts were hatched in sea water of $35 \mathrm{ppt}$ salinity at a room temperature of $29^{\circ} \mathrm{C}$ under continuous illumination and aeration. Hatched instar I nauplii were introduced at a density of 50 nauplii $/ 250 \mathrm{ml}$ into glass conical flasks containing salt solutions of $35,65,80,100$ and $120 \mathrm{ppt}$. The solutions at each of the salinities were maintained at temperatures of 21,25 and $29^{\circ} \mathrm{C}$ with continuous aeration. Additionally, 140 and $180 \mathrm{ppt}$ salinities were also used at $29^{\circ} \mathrm{C}$ and at $35^{\circ} \mathrm{C}$. The higher salinities were used only at the higher temperatures because, under field conditions in Artemia ponds, the high salinity levels occur only under increased evaporation rates associated with high temperatures. All experiments were conducted in triplicate. The solutions of different salinities were prepared by dissolving commercial salt in sea water. Experiments at $21^{\circ} \mathrm{C}$ and $25^{\circ} \mathrm{C}$ temperatures were carried out in a temperature controlled room in thermostatically controlled water baths. Experiments at $35^{\circ} \mathrm{C}$ were carried out in a constant temperature water bath (Kottermann).

The feeding schedule ${ }^{1}$ was as follows: Artemia nauplii were fed daily with the alga Dunaliella sp. commencing at a density of $6.0 \times 10^{6}$ and $8.4 \times 10^{6}$ cells per day at $21^{\circ} \mathrm{C}$ and $25^{\circ} \mathrm{C}$, respectively, and at $10.8 \times 10^{6}$ cells per day at $29^{\circ} \mathrm{C}$ and $35^{\circ} \mathrm{C}$, doubling the algal densities every two days. Algal cultures were counted using a haemocytometer and the required concentrations for feeding were prepared after centrifugation. Faecal matter was siphoned out and $25 \%$ of the medium was renewed every $2 \mathrm{~d}$. Survival was checked every $3 \mathrm{~d}$ up to $14 \mathrm{~d}$. Body lengths were determined every $3 \mathrm{~d}$ for a random sample of 20 animals per flask. For body length measurements, each animal was transferred on to a cavity slide and the water was gently drawn out using a paper towel. The total length was measured from the anterior margin of the head in front of the ocellus to the base of the caudal furca ${ }^{5}$ using a binocular microscope fitted with a calibrated eyepiece micrometer.

Ten adult animals were placed individually in glass vials of $50 \mathrm{ml}$ capacity at $29^{\circ} \mathrm{C}$ in the salinities of 35,100 and 120 ppt which were the salinities in which animals attained adult stage and feeding was continued. The salinity was gradually increased at $4 \mathrm{ppt}$ day ${ }^{-1}$ by addition of a concentrated salt solution. The vials were examined daily for the presence of nauplii or cysts and counts were made of any nauplii or cysts that were produced. 


\section{RESULTS}

Survival: Percentage survival at different temperatures and salinities is illustrated in Figure 1 a-d. A rapid reduction in survival was seen at $21^{\circ} \mathrm{C}$ in all salinity levels except in 65ppt in which survival had stabilized at $48 \%$ by day 14 . At $25^{\circ} \mathrm{C}$ survival was high in $100 \mathrm{ppt}$ and $120 \mathrm{ppt}$ salinities.

(a) $21^{\circ} \mathrm{C}$

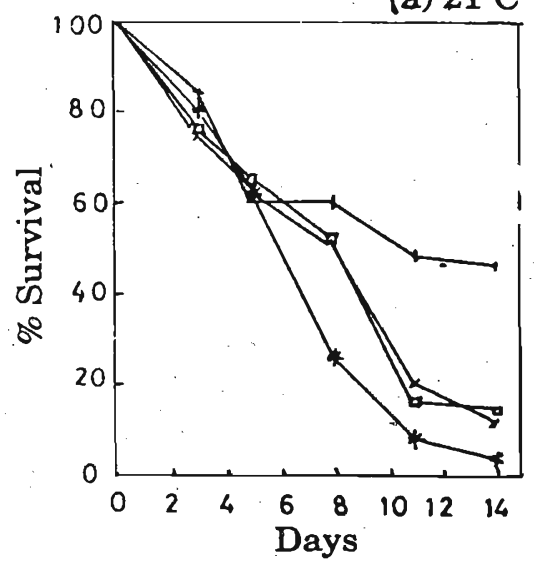

(c) $29^{\circ} \mathrm{C}$

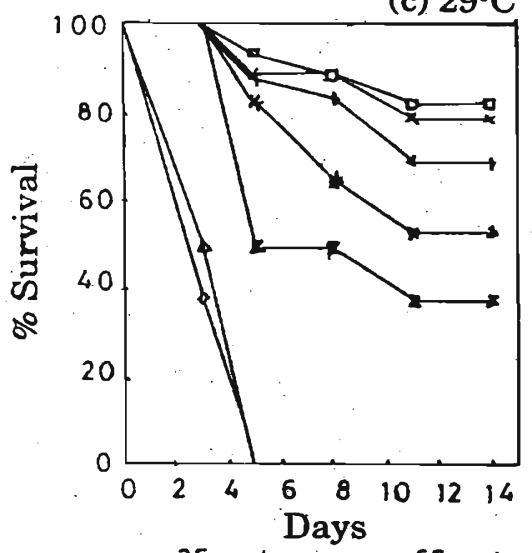

$-2-35 p p t \div 65 p p t$ (b) $25^{\circ} \mathrm{C}$

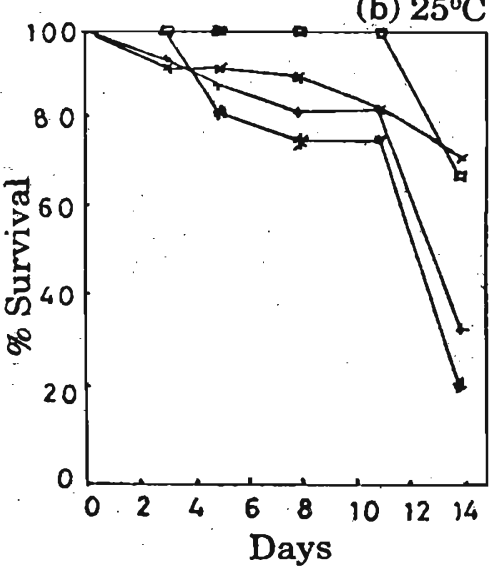

(d) $35^{\circ} \mathrm{C}$

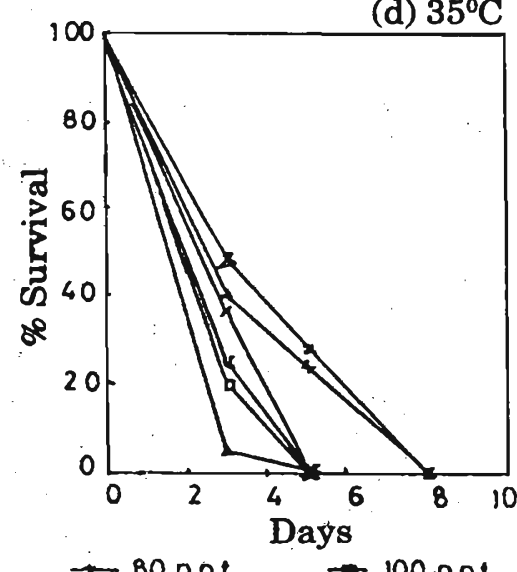

$-180 \mathrm{ppt}$

Figure 1 a-d: Percentage survival in Artemia parthenogenetica at varying temperatures and salinities.

At room temperature of $29^{\circ} \mathrm{C}, 100 \%$ mortality was observed by day 5 in 140ppt and 180ppt salinities. Until day 3 there was $100 \%$ survival in the salinity levels ranging from $35 \mathrm{ppt}$ to $120 \mathrm{ppt}$. Survival decreased rapidly from $100 \%$ at day 3 to $48 \%$ at day 5 at 35 ppt salinity. There was $68 \%$ and $52 \%$ survival at salinities of 65pt and 80ppt at day 14. The highest survival (82\%) at day 14 was attained in $100 \mathrm{ppt}$ salinity followed by $78 \%$ survival in $120 \mathrm{ppt}$ salinity. The lowest survival $(37 \%)$ at room temperature was in 35pt salinity at dáy 14 . 
At $35^{\circ} \mathrm{C}$ there was a rapid decrease in survival within two days of the experiment resulting in complete mortality by day 5 at all salinity levels except at the low salinity levels of 35 and 65 ppt. Even at these 35 and $65 \mathrm{ppt}$ salinities, $100 \%$ mortality occurred by day 8 .

Growth: The mean length of instar I nauplius of Sri Lankan Artemia was $475.4 \mu \mathrm{m}$. The mean lengths of Artemia at different temperatures and salinities are illustrated in Figure 2 a-c. Length measurements were discontinued after 25 days or when there was more than $75 \%$ mortality.
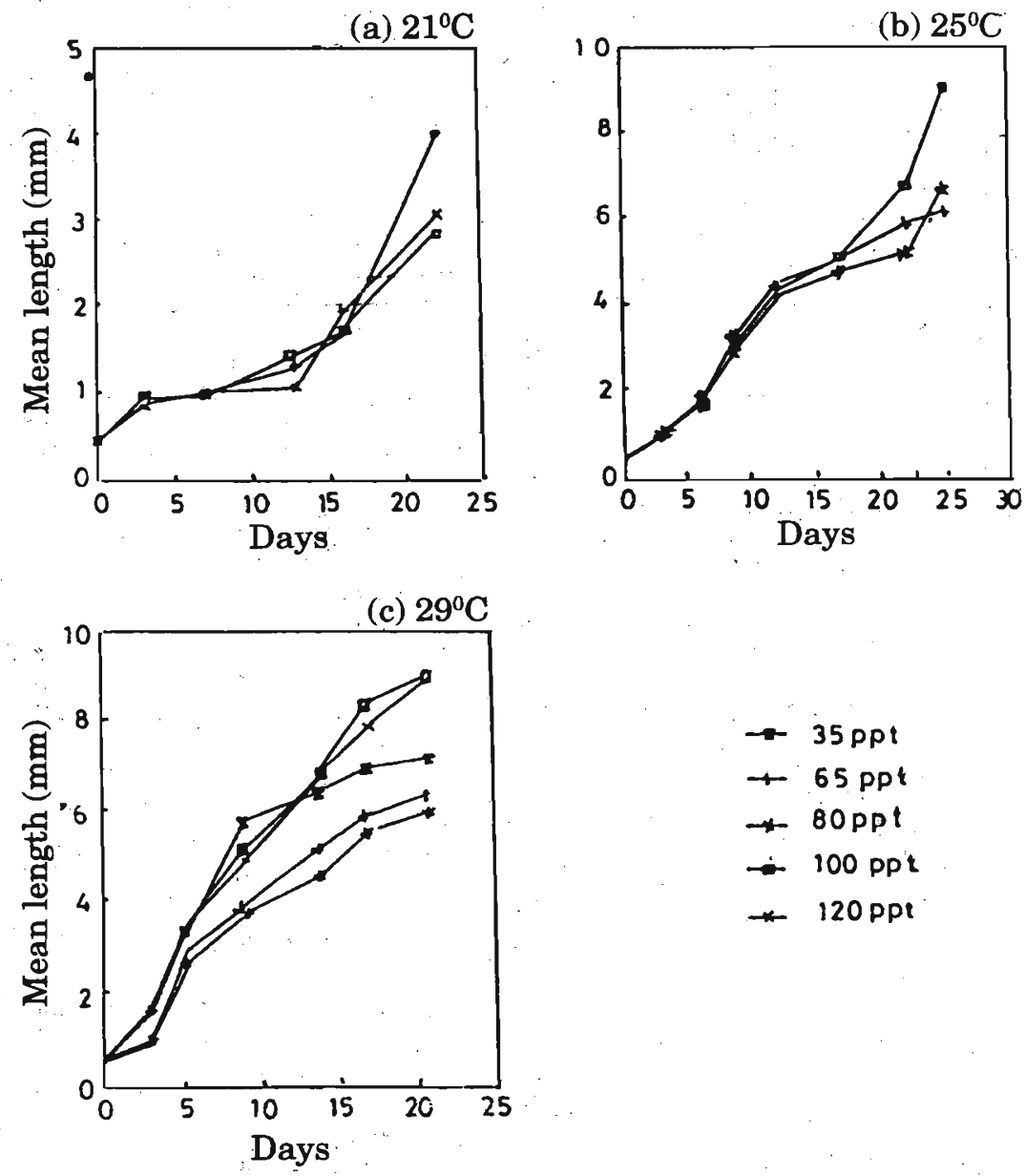

Figure 2 a-c: Variation in mean body length $(\mathrm{mm})$ in Artemia parthenogenetica at varying temperatures and salinities.

Fecundity: Reproductive characteristics of Artemia are summarized in Table 1. Artemia did not attain reproductive maturity at any of the tested salinities at $21^{\circ} \mathrm{C}$. A slight appearance of broodpouches was observed at 65,80 and $100 \mathrm{ppt}$ salinities at $25^{\circ} \mathrm{C}$. They grew only to pre-adult stage at $25^{\circ} \mathrm{C}$. At $29^{\circ} \mathrm{C}$ in both 100 and 120 ppt salinity, Artemia attained reproductive maturity in 14 to 15 days within a length range of 6.9 to $7.0 \mathrm{~mm}$. 
Table 1: Reproduction and fecundity of Artemia parthenogenetica in laboratory experiments at different temperature and salinity combinations.

\begin{tabular}{|c|c|c|c|c|c|c|c|c|}
\hline \multicolumn{2}{|c|}{ Experimental } & \multirow{3}{*}{$\begin{array}{c}\text { conditions } \\
\text { Age at } \\
\text { maturity } \\
\text { (days) }\end{array}$} & \multicolumn{6}{|c|}{ Reproduction and Fecundity } \\
\hline \multirow[t]{2}{*}{$\mathrm{T}\left({ }^{\circ} \mathrm{C}\right)$} & \multirow[t]{2}{*}{$\mathrm{S}(\mathrm{ppt})$} & & \multicolumn{3}{|c|}{ Naupliar production } & \multicolumn{3}{|c|}{ Cyst production } \\
\hline & & & nos/parent & $\begin{array}{c}\text { Age } \\
\text { (days) }\end{array}$ & $\begin{array}{l}\text { Salinity } \\
\text { (ppt) }\end{array}$ & nos/parent & $\begin{array}{c}\text { Age } \\
\text { (days) }\end{array}$ & $\begin{array}{c}\text { Salinity } \\
\text { (ppt) }\end{array}$ \\
\hline \multirow[t]{4}{*}{21} & 65 & n.a. & & n.p. & & & n.p. & \\
\hline & 80 & n.a. & & n.p. & & & n.p. & \\
\hline & 100 & n.a. & & n.p. & & & n.p. & \\
\hline & 120 & n.a. & & n.p. & & & n.p. & \\
\hline \multirow[t]{4}{*}{25} & 65 & n.a. & & n.p. & & & n.p. & \\
\hline & 80 & n.a. & & n.p. & & & n.p. & \\
\hline & 100 & n.a. & & n.p. & & & n.p. & \\
\hline & 120 & n.a. & & n.p. & & & n.p. & \\
\hline \multirow[t]{7}{*}{29} & 35 & 14 & 68 & 15 & 35 & 37 & 46 & 132 \\
\hline & 65 & n.a. & & n.p. & & & n.p. & \\
\hline & 80 & n.a. & & n.p. & & & n.p. & \\
\hline & 100 & 14 & 56 & 15 & 100 & 38 & 25 & 136 \\
\hline & 120 & 15 & & n.p. & & 36 & 26 & 140 \\
\hline & 140 & n.a. & & n.p. & & & n.p. & \\
\hline & 180 & n.a. & & n.p. & & & n.p. & \\
\hline \multirow[t]{7}{*}{35} & 35 & n.a. & & n.p. & & & n.p. & \\
\hline & 65 & n.a. & & n.p. & & & n.p. & \\
\hline & 80 & n.a. & & n.p. & & & n.p. & \\
\hline & 100 & n.a. & & n.p. & & & n.p. & \\
\hline & 120 & n.a. & & n.p. & & & n.p. & \\
\hline & 140 & n.a. & & n.p. & & & n.p. & \\
\hline & 180 & n.a. & & n.p. & & & n.p. & \\
\hline
\end{tabular}

At $100 \mathrm{ppt}$ salinity at $29^{\circ} \mathrm{C}$ adults with broodpouches were observed on day 14 , and on day 15 five adults released nauplii at 56 numbers adult ${ }^{-1}$ (Table 1 ). With gradual increase in salinity, nauplii were released at 62 numbers adult ${ }^{-1}$ at $108 \mathrm{ppt}$ after an interval of 4 days from the initial release of nauplii. There was no release of nauplii by Artemia from 108 to $136 \mathrm{ppt}$ salinity. Two animals released cysts at 38 numbers adult ${ }^{-1}$ and 36 numbers adult ${ }^{-1}$ at 136 ppt on day 25 and 140pt on day 26, respectively. There was $100 \%$ mortality in Artemia two days after the salinity was increased to $140 \mathrm{ppt}$.

In the treatments maintained at $29^{\circ} \mathrm{C}$ and $120 \mathrm{ppt}$, adults with broodpouches were observed on day 15 . As salinity was gradually increased at a rate of $4 \mathrm{ppt}$ per day cysts were released at $140 \mathrm{ppt}$ at $36 \mathrm{cysts}^{\text {adult }} \mathrm{tinitially}^{-1}$ at day 24 , and 40 cysts adult ${ }^{-1} 4$-days thereafter at the same salinity. Ovoviviparity was not observed in these adults.

Artemia initially reproduced ovoviviparously in 35ppt at 68 nauplii per female and as salinity was increased upto $100 \mathrm{ppt}$, ovoviviparity re-occurred at 
3 to 4 day intervals. Oviparity occurred at $132 \mathrm{ppt}$ and continued upto $148 \mathrm{ppt}$ salinity after which there was $100 \%$ mortality. Artemia did not reproduce from $100 \mathrm{ppt}$ to $132 \mathrm{ppt}$ salinity. The highest number of nauplii (160/female) were produced at $60 \mathrm{ppt}$ followed by 135 nauplii/female at $40 \mathrm{ppt}$ salinity. With regard to cyst production, fecundity ranged from 37 to 42 cysts/female.

\section{DISCUSSION}

The best conditions for survival of Sri Lankan Artemia from hatching to maturity were at $100 \mathrm{ppt}$ and $25^{\circ} \mathrm{C}$ with 100 and $120 \mathrm{ppt}$ salinities at $25^{\circ}$ and $29^{\circ} \mathrm{C}$ also supporting high survival rates. These conditions should therefore be maintained in ponds for favourable survival during the growth phase of Sri Lankan Artemia. The higher salinities (140 and $180 \mathrm{ppt}$ ) at $29^{\circ} \mathrm{C}$ and the range of salinities from 65 to $140 \mathrm{ppt}$ at $35^{\circ} \mathrm{C}$ are very unfavourable to the younger stages and should be avoided at the inoculation stage of pond culture. High mortalities at higher temperatures that were recorded in the present study were also evident under field culture conditions where total mortality of Sri Lankan Artemia populations occurred when pond waters at Palavi reached $33^{\circ} \mathrm{C} .{ }^{10} \mathrm{Such}$ detrimental effects of high temperature on survival dictate that culture conditions should be manipulated so as to avoid pond waters reaching high temperature values, which tends to occur particularly during the later periods of the dry season.

Survival studies on a variety of other Artemia strains have shown increased survival to occur over a wider range of temperatures than reported by us, with survival in excess of $90 \%$ being reported over a 20 to $29^{\circ} \mathrm{C}$ temperature range in the Indian Tuticorin Artemia and survival decreasing to $50 \%$ with increase in temperature to 32 to $33^{\circ} \mathrm{C} .{ }^{1}$ Artemia from Iraq also displayed higher survival at lower temperatures of 15 to $25^{\circ} \mathrm{C}$ but became motionless at $35^{\circ} \mathrm{C}$ and further temperature increases (to 42 to $44^{\circ} \mathrm{C}$ ) resulted in total mortality. ${ }^{11}$ For the Indian Tuticorin strain, the preferred temperature was at $27^{\circ} \mathrm{C}$ and optimal survival occurred at 30 to 40 ppt salinity range. ${ }^{12}$

Reports indicate a wide range of variability in the survival and growth of Artemia at different salinities and temperatures, e.g. A. franciscana from Lake Grassmere, New Zealand, achieved over $90 \%$ survival and fastest growth at 20 to $28^{\circ} \mathrm{C}$ in 100 to 170 ppt salinity range $^{8} ; 50$ to 100 ppt salinity range for increased growth in Tuticorin Artemia ${ }^{13}$; a higher growth rate in Artemia from Sambhar Lake, India reared at $12.5 \%$ (corresponding to $125 \mathrm{ppt}$ ) salinity than at a low salinity of $6.5 \%{ }^{6}$ (corresponding to $65 \mathrm{ppt}$ ). These reports indicate that the extent to which growth is influenced by the salinity of the external medium varies with the stock and sex of Artemia.$^{5}$

Even though it had been found that reproductive maturity in parthenogenetic females from Sri Lanka was attained in 15 to 17 days when reared at $35 \mathrm{ppt}$ and at $140 \mathrm{ppt}$ at $25^{\circ} \mathrm{C},{ }^{5}$ in the present study only a slight development of broodpouches was observed in Sri Lanka Artemia at $25^{\circ} \mathrm{C}$ at the low salinities tested. Artemia from Sambhar Lake, India, became reproductively mature in 15 to 17 days when 
reared at $125 \mathrm{ppt}$ salinity while those reared at a low salinity of $6.5 \%$ became reproductively mature in 20 to 25 days. ${ }^{6}$ The tolerance threshold of Artemia is strain-dependant and as far as optimum temperature is concerned it has been observed that there are probably as many temperature optima as there are Artemia habitats. ${ }^{4}$

In the present study Artemia reproduced ovoviviparously at $100 \mathrm{ppt}$ and oviparous reproduction occurred later when salinity was increased gradually to 132 ppt. Similarly it had been found that the first brood of offspring in Artemia was ovoviviparous both in the wild and in the laboratory. ${ }^{14}$ Ovoviviparous reproduction, however, was not observed in Sri Lankan Artemia cultured in $120 \mathrm{ppt}$ salinity or at increase of salinity from 120 to $140 \mathrm{ppt}$ since these animals produced cysts at $136 \mathrm{ppt}$ without prior nauplii production. Under field conditions at Mahalewaya saltern Artemia commenced cyst production at a similar salinity of 132 ppt. ${ }^{3}$ Observations on cyst production reported here point to the possibility of manipulating salinity values in the salterns for triggering cyst production. Reports have indicated that in parthenogenetic populations, the percent of offspring born viviparously was higher than encysted offspring. ${ }^{15}$ Fecundity observations from the present study lend support to this viewpoint. The salinity range of 100 to 120 ppt observed in the Mahalewaya salterns as carrying the highest populations of Sri Lankan Artemia relate favourably to the observations made under laboratory conditions. ${ }^{10} \mathrm{~A}$ salinity range of 100 to $120 \mathrm{ppt}$ in combination with a temperature range of 25 to $29^{\circ} \mathrm{C}$ are recommended as optimal ranges for these two parameters for survival, growth and reproduction of Artemia from Sri Lanka.

\section{Acknowledgments}

This work was funded by the Natural Resources, Energy and Science Authority (RG/87/B/3). Laboratory facilities were provided by the Department of Zoology, University of Colombo and the National Aquatic Resources Agency.

\section{References}

1. Vanhaecke P., Siddall S. E. \& Sorgeloos P. (1984). International study on Artemia. XXXII. Combined effects of temperature and salinity on the survival of Artemia of various geographical origin. Journal of Experimental Marine Biology and Ecology 80:259-275.

2. Sunderam R. I. M. \& Royan J. P. (1984). Note on the occurrence of Artemia in Sri Lanka. Journal of the National Aquatic Resources Agency 31:123-125.

3. Kuruppu M. M. \& Ekaratne S. U. K. (1989). Nutritional evaluation of Sri Lankan Artemia parthenogenetica for use in larval rearing. In: Fish Nutrition Research in Asia. (Ed. S. S. De Silva) pp. 112-117. Proceedings of the Third Asian Fish Nutrition Network Meeting. Asian Fisheries Society Special Publication 4. Asian Fisheries Society, Manila, Philippines. 
4. Persoone G. \&. Sorgeloos P. (1980). General aspects of the ecology and biogeography of Artemia. In: The Brine Shrimp Artemia. Vol. 3. Ecology, culturing, use in aquaculture. (Eds. G. Persoone, P. Sorgeloos, O. Roels and E. Jaspers) pp. 3-24. Universa Press, Wetteren, Belgium.

5. Gilchrist B. M. (1960). Growth and form of the brine shrimp Artemia salina (L.). Proceedings of the Zoological Society, London 134(2):221-235.

6. Baid I. C. (1963). The effect of salinity on the growth and form of Artemia salina (L.). Journal of Experimental Zoology 153: 279-283.

7. Wear R.G. \& Haslett S.J. (1986). Effects of temperature and salinity on the biology of Artemia franciscana Kellogg from Lake Grassmere, New Zealand. 1. Growth and mortality. Journal of Experimental Marine Biology and Ecology 98:153-166.

8. Wear R.G., Haslett S.J. \& Alexander N.L. (1986). Effects of temperature and salinity on the biology of Artemia franciscana Kellogg from Lake Grassmere, New Zealand. 2. Maturation, fecundity and generation times. Journal of Experimental Marine Biology and Ecology 98:167-183.

9. Sorgeloos P., Lavens P., Leger Ph., Tackaert W. \&Versichele D. (1986). Manual for the culture and use of brine shrimp Artemia in aquaculture. pp. 319. Universa Press, Wetteren, Belgium.

10. Kuruppu M.M. \& Ekaratne S.U.K. (1994). Culture potential of Artemia parthenogenetica in Sri Lanka. Proceedings of the First Annual Scientific Sessions of the National Aquatic Resources Agency, 1993. National Aquatic Resources Agency, Colombo 15, Sri Lanka. pp. 25-36.

11. Al-Uthman H.S. (1971). Ecological observations on Artemia salina (L.) (Anostraca: Artemiidae) in Iraq. Bulletin of the Biological Research Centre 5:49-65.

12. Royan J.P. (1980). Laboratory and field studies on an Indian strain of the brine shrimp Artemia. In: The Brine Shrimp Artemia. Vol. 3. Ecology, culturing, use in aquaculture. (Eds. G. Persoone, P. Sorgeloos, O. Roels and E. Jáspers) pp. 223-230. Universa Press, Wetteren, Belgium.

13. Balasunderam C. \& Kumaraguru A. K. (1987). Laboratory studies on growth and reproduction of Artemia (Tuticorin strain). In: Artemia Research and its applications. Vol.3. Ecology, culturing, use in aquaculture. (Eds. P. Sorgeloos, D.A. Bengtson, W. Decleir and E. Jaspers) pp. 331-338. Universa Press, Wetteren, Belgium. 
14. D'Agostino A. (1980). The vital requirements of Artemia : physiology and nutrition. In: The Brine Shrimp Artemia. Vol. 2. Physiology, biochemistry, molecular biology. (Eds. G. Persoone, P. Sorgeloos, O. Roels and E. Jaspers) pp. 55-82. Universa Press, Wetteren, Belgium.

15. Browne R.A., Sallee S.E., Grosch D.S., Segreti W.O. \& Purser S.M. (1984). Partitioning genetic and environmental components of reproduction and lifespan in Artemia. Ecology 65: 949-960. 